\title{
Motivasi Intrinsik, Kinerja dan Aktualisasi Diri: Kajian Konseptual Perkembangan Teori
}

\author{
Akhmad Lutfi ${ }^{1}$, Ahmad Yahya Surya Winata ${ }^{2 *}$ \\ ${ }^{1}$ Mahasiswa Magister Manajemen Fakultas Ekonomi dan Bisnis Universitas Trunojoyo Madura \\ ${ }^{2}$ Dosen Fakultas Ekonomi dan Bisnis Universitas Trunojoyo Madura \\ Jl. Raya Telang No 02 Kamal Bangkalan Madura Jawa Timur 69162
}

*Email: ahmadsuryawinata@trunojoyo.ac.id

Naskah diterima 3 Agustus 2020, Revisi 17 September 2020, Terbit 29 Oktober 2020

\begin{abstract}
Abstrak
DOI: doi.org/10.21107/pamator.v13i2.8526

Tidak diragukan lagi bahwa motivasi adalah hal penting yang harus ada di dalam diri karyawan dalam melaksanakan tugas didalam sebuah organisasi. Kinerja salah satunya ditentukan oleh adanya motivasi, salah satunya adalah motivasi yang timbul dan berasal dari dalam diri atau disebut motivasi internal. Sangat banyak peneliti yang mengaitkan motivasi internal dengan kinerja dan kebutuhan seseorang untuk mengaktualisasikan diri. Makalah ini akan menyajikan kajian konseptual dari beberapa peneliti tentang teori kaitan motivasi internal dengan kinerja dan kebutuhan untuk mengaktualisasi diri. Beberapa peneliti sepakat mengatakan bahwa motivasi intrinsik sangatlah penting, selain mempengaruhi kinerja, motivasi intrinsik juga merupakan wujud untuk memenuhi kebutuhkan untuk mengaktualisasikan diri.
\end{abstract}

Kata Kunci: motivasi, intrinsik, aktualisasi diri, kinerja

\section{PENDAHULUAN}

Salah satu kebutuhan penting manusia dalam bekerja adalah motivasi. Motivasi merupakan suatu penggerak dari dalam diri seseorang untuk melakukan atau mencapai suatu tujuan. Dalam beberapa hal, motivasi dapat berfungsi sebagai pengarah yang artinya mengarahkan seseorang dalam berbuat untuk mencapai tujuan yang diinginkan, serta motivasi juga dapat berfungsi sebagai penggerak yang artinya menggerakkan tingkah laku seseorang. Besar kecilnya motivasi akan menentukan cepat lambatnya suatu pekerjaan dapat diselesaikan. Sangat banyak peneliti yang khusus mendefinisikan motivasi, diantaranya Schiffman \& Kanuk (2001) berpendapat mengenai motivasi, dimana: "motivation can be described as the driving force within individuals that impels them to action".

Motivasi dapat dideskripsikan sebagai kekuatan pendorong dalam diri seseorang yang memaksanya untuk melakukan suatu tindakan tertentu. Selain itu McClelland (2008) juga mengatakan bahwa: "achievement motivation is an activity to overcome or defeat a chalengge that aims for progress and growth". Motivasi berprestasi merupakan suatu kegiatan untuk mengatasi atau mengalahkan suatu tantangan yang bertujuan untuk kemajuan dan pertumbuhan.

Motivasi sebagai sebuah proses untuk tercapainya suatu tujuan. Menurut Herzberg dalam Miner (2005), ada dua jenis faktor yang mendorong seseorang untuk berusaha mencapai kepuasan diri. Dua faktor itu disebutnya faktor intrinsik dan faktor ekstrinsik. Faktor intrinsik memotivasi seseorang untuk berusaha mencapai kepuasan, yang termasuk di dalamnya adalah achievement, pengakuan, kemajuan tingkat kehidupan, dan sebagainya, sedangkan faktor ekstrinsik memotivasi seseorang dari luar untuk mencapai kepuasan, termasuk di dalamnya adalah hubungan antar manusia, imbalan, kondisi lingkungan, dan sebagainya.

Maslow (1965) mengatakan bahwa pada dasarnya semua manusia memiliki kebutuhan pokok. Salah satu diantaranya yaitu aktualisasi diri dimana kebutuhan akan aktualisasi diri itu sendiri dengan mendapatkan kepuasan dan menyadari potensi yang ada. McGregor (1966) mengemukakan mengenai dua pandangan manusia yaitu teori $X$ (negatif) dan teori $Y$ (positif), Menurut teori $X$ beberapa pengandaian yang dipegang manajer yaitu : (1) karyawan tidak menyukai kerja mereka 
harus diawasi atau diancam dengan hukuman untuk mencapai tujuan; (2) karyawan akan menghindari tanggung jawab; (3) kebanyakan karyawan menaruh keamanan diatas semua faktor yang dikaitkan dengan kerja. Kontras dengan pandangan negatif ini mengenai kodrat manusia ada empat teori $Y$ : (1) karyawan dapat memandang kerjasama dengan sewajarnya seperti istirahat dan bermain; (2) orang akan menjalankan pengarahan diri dan pengawasan diri jika mereka komit pada sasaran; (3) rata-rata orang akan menerima tanggung jawab; (4) kemampuan untuk mengambil keputusan inovatif.

Dari beberapa filosofi tersebut dapat dianalogikan bahwa dengan adanya motivasi baik intrinsik maupun ekstrinsik sebagai wujud dari aktualisasi diri akan mendorong karyawan untuk bekerja lebih untuk menuju kesuksesan dan menghindari kegagalan. Dengan kata lain motivasi karyawan mengeksplorasi pemikiran mereka dengan membuat ide-ide baru dengan kreativitas mereka untuk mencapai suatu tujuan.

Motivasi dapat berfungsi sebagai pengarah yang artinya mengarahkan perbuatan mencapai tujuan yang diinginkan, serta motivasi juga dapat berfungsi sebagai penggerak yang artinya menggerakkan tingkah laku seseorang. Besar kecilnya motivasi akan menentukan cepat lambatnya suatu pekerjaan.

Motivasi intrinsik adalah motivasi yang berasal dari dalam individu, yang berarti seseorang melakukan suatu tindakan tidak berdasarkan dari dorongan-dorongan atau faktor-faktor lain yang berasal dari luar diri, contohnya self actualization need (keinginan untuk mengaktualisasikan diri) (Maslow, 1965). Terbentuknya motivasi intrinsik itu sendiri terjadi karena adanya keinginan yang timbul secara alamiah dari dalam yang membangkitkan semangat menggerakkan seseorang untuk melakukan sesuatu untuk mencapai kepuasan atau tujuan, karena manusia selalu mempunyai naluri untuk mencapai sesuatu maka melalui motivasi intrinsik inilah dapat mendorong seseorang untuk terlibat dalam sebuah aktivitas dalam rangka merasakan kenikmatan sensasional (Vallerand, et.al., 1992).

Artikel ini disusun sebagai kajian teoritis yang menghubungkan motivasi intrinsik dengan aktualisasi diri dan kinerja. Sebagai bahan kajian akan digambarkan beberapa pendapat peneliti tentang motivasi intrinsik diantaranya adalah : Titmuss, R. M. (1970), Deci, E. L. (1971 dan 1975), Edward, D. \& Ryan, R. (1985), Deci, E. L., \& Ryan, R. M. (1985), Pittman dan Heller (1987), Amabile, T. M., Hill, K. G., Hennessey, B. A., \& Tighe, E. (1994), Amabile, T. M., Conti, R., Coon, H., Lazenby, J., \& Herron, M. (1996), BenNer, Putterman. (1998), Deci., \& Ryan (2000) dan Dysvik, A., \& Kuvaas, B. (2011).

\section{KAJIAN TEORITIS}

Beberapa pendapat peneliti tentang motivasi intrinsik menyebutkan bahwa motivasi intrinsik sangat berkaitan erat dengan kebutuhan seseorang untuk mengaktualisasi dirinya. Bahkan ada yang beranggapan motivasi intrinsik seseorang yang paling penting dalam bekerja adalah pekerjaan itu sendiri. Hal inilah yang menyebabkan motivasi intrinsik sangat mempengaruhi kinerja. Disamping itu ada hasil penelitian yang mengagetkan bahwa motivasi eksternal seperti imbalan berupa materi dapat merusak motivasi internal. Secara garis besar, beberapa pendapat peneliti digambarkan dalam tabel dibawah ini.

Tabel 1. Definisi dan Penekan Konsep Teori Motivasi Intrinsik

\begin{tabular}{|l|l|l|}
\hline \multicolumn{1}{|c|}{ Author } & \multicolumn{1}{|c|}{ Definisi } & \multicolumn{1}{c|}{$\begin{array}{c}\text { Penekanan } \\
\text { Konsep }\end{array}$} \\
\hline $\begin{array}{l}\text { Titmuss, R. } \\
\text { M. (1970) }\end{array}$ & $\begin{array}{l}\text { Membayar untuk } \\
\text { mendapatkan darah } \\
\text { akan merusak nilai-nilai } \\
\text { sosial dan motivasi, dan } \\
\text { mengarah pada } \\
\text { kemauan yang lebih } \\
\text { rendah untuk }\end{array}$ & $\begin{array}{l}\text { Faktor eksternal } \\
\text { dapat merusak } \\
\text { motivasi intrinsik }\end{array}$ \\
\hline $\begin{array}{l}\text { Deci, E. L. } \\
\text { (1971) }\end{array}$ & $\begin{array}{l}\text { Umpan balik kinerja } \\
\text { positif meningkatkan } \\
\text { motivasi intrinsik }\end{array}$ & $\begin{array}{l}\text { Motivasi intrinsik } \\
\text { dan kinerja }\end{array}$ \\
\hline $\begin{array}{l}\text { Deci, E. L. } \\
\text { (1975) }\end{array}$ & $\begin{array}{l}\text { Seseorang dikatakan } \\
\text { secara intrinsik } \\
\text { termotivasi untuk } \\
\text { melakukan suatu } \\
\text { aktivitas ketika dia tidak } \\
\text { menerima hadiah yang } \\
\text { jelas kecuali aktivitas itu } \\
\text { sendiri. }\end{array}$ & $\begin{array}{l}\text { Motivasi intrinsik } \\
\text { dan aktualisasi } \\
\text { diri }\end{array}$ \\
\hline $\begin{array}{l}\text { Motivasi intrinsik } \\
\text { \& Ryan, R. } \\
\text { (1985) }\end{array}$ & $\begin{array}{l}\text { mengacu pada proses di } \\
\text { mana individu tertarik } \\
\text { pada tugas itu sendiri, } \\
\text { dan diarahkan sendiri } \\
\text { untuk terlibat dalam } \\
\text { pekerjaan }\end{array}$ & $\begin{array}{l}\text { Motivasi intrinsik } \\
\text { dan aktualisasi } \\
\text { diri }\end{array}$ \\
\hline
\end{tabular}




\begin{tabular}{|c|c|c|}
\hline Author & Definisi & $\begin{array}{l}\text { Penekanan } \\
\text { Konsep }\end{array}$ \\
\hline $\begin{array}{l}\text { Deci, E. L., } \\
\text { \& Ryan, R. } \\
\text { M. (1985) }\end{array}$ & $\begin{array}{l}\text { Melakukan suatu } \\
\text { kegiatan untuk } \\
\text { kepuasan yang melekat }\end{array}$ & $\begin{array}{l}\text { Motivasi intrinsik } \\
\text { dan aktualisasi } \\
\text { diri }\end{array}$ \\
\hline $\begin{array}{l}\text { Pittman } \\
\text { dan Heller } \\
\text { (1987) }\end{array}$ & $\begin{array}{l}\text { Imbalan dapat merusak } \\
\text { motivasi intrinsik }\end{array}$ & $\begin{array}{l}\text { Faktor eksternal } \\
\text { dapat merusak } \\
\text { motivasi intrinsik }\end{array}$ \\
\hline $\begin{array}{l}\text { Amabile, T. } \\
\text { M., Hill, K. } \\
\text { G., } \\
\text { Hennessey, } \\
\text { B. A., \& } \\
\text { Tighe, E. } \\
\text { (1994) }\end{array}$ & $\begin{array}{l}\text { Motivasi intrinsik } \\
\text { mengacu pada } \\
\text { melakukan kegiatan } \\
\text { untuk kepentingan dan } \\
\text { kesenangan dari } \\
\text { pekerjaan itu sendiri }\end{array}$ & $\begin{array}{l}\text { Motivasi intrinsik } \\
\text { dan aktualisasi } \\
\text { diri }\end{array}$ \\
\hline $\begin{array}{l}\text { Amabile, T. } \\
\text { M., Conti, } \\
\text { R., Coon, } \\
\text { H., } \\
\text { Lazenby, } \\
\text { J., \& } \\
\text { Herron, M. } \\
\text { (1996) }\end{array}$ & $\begin{array}{l}\text { Motivasi intrinsik sering } \\
\text { muncul dari reaksi } \\
\text { positif individu terhadap } \\
\text { tugas itu sendiri, seperti } \\
\text { minat, keterlibatan, } \\
\text { keingintahuan, } \\
\text { kepuasan, atau } \\
\text { tantangan positif, yang } \\
\text { berfungsi sebagai jenis } \\
\text { hadiah pekerjaan }\end{array}$ & $\begin{array}{l}\text { Motivasi intrinsik } \\
\text { dan aktualisasi } \\
\text { diri }\end{array}$ \\
\hline $\begin{array}{l}\text { Ben-Ner., \& } \\
\text { Putterman. } \\
\text { (1998) }\end{array}$ & $\begin{array}{l}\text { Motivasi intrinsik dapat } \\
\text { menunjukkan } 2 \text { hal, } \\
\text { yaitu } \\
\text { kesenangan/ketertarikan } \\
\text { pribadi khususnya ttg } \\
\text { pengembangan } \\
\text { profesional, serta } \\
\text { ketertarikan pada hal } \\
\text { lainnya seperti perhatian } \\
\text { pada kebutuhan } \\
\text { komunitasnya }\end{array}$ & $\begin{array}{l}\text { Motivasi intrinsik } \\
\text { dan kinerja }\end{array}$ \\
\hline $\begin{array}{l}\text { Deci., \& } \\
\text { Ryan } \\
(2000)\end{array}$ & $\begin{array}{l}\text { tidak ada fenomena } \\
\text { tunggal yang } \\
\text { mencerminkan potensi } \\
\text { positif dari sifat manusia } \\
\text { sebanyak motivasi } \\
\text { intrinsik, kecenderungan } \\
\text { yang melekat untuk } \\
\text { mencari hal baru dan } \\
\text { tantangan, untuk } \\
\text { memperluas dan } \\
\text { menggunakan kapasitas } \\
\text { seseorang, untuk } \\
\text { mengeksplorasi, dan } \\
\text { untuk belajar }\end{array}$ & $\begin{array}{l}\text { Motivasi intrinsik } \\
\text { dan kinerja }\end{array}$ \\
\hline $\begin{array}{l}\text { Dysvik, A., } \\
\text { \& Kuvaas, } \\
\text { B. (2011) }\end{array}$ & $\begin{array}{l}\text { Motivasi intrinsik } \\
\text { membuat orang } \\
\text { cenderung } \\
\text { meningkatkan } \\
\text { keterlibatan mereka } \\
\text { dalam kegiatan terkait } \\
\text { kerja }\end{array}$ & $\begin{array}{l}\text { Motivasi intrinsik } \\
\text { dan kinerja }\end{array}$ \\
\hline
\end{tabular}

HASIL PEMBAHASAN

Faktor Eksternal Yang Merusak Motivasi Intrinsik

Beberapa peneliti beranggapan bahwa ada faktor eksternal yang dapat merusak motivasi intrinsik. Titmuss (1970) menggambarkan kenyataan bahwa untuk mendapatkan darah untuk meyelamatkan hidup seseorang harus membayar, itu melemahkan nilai-nilai sosial dan motivasi, hal itu menyebabkan berkurangnya motivasi atau kemauan seseorang untuk menyumbangkan darah. Hal ini dapat dipahami bahwa motivasi intrinsik untuk berbuat baik akan terpengaruh secara negatif karena kenyataan perbuatan baik tersebut bermanfaat bagi orang lain dengan dinilai sebagai materi. Lebih gamblang lagi Pittman dan Heller (1987) mengatakan bahwa imbalan dapat merusak motivasi intrinsik. Ketika kompensasi menjadi tujuan utama dalam bekerja, berarti kompensasi telah merusak motivasi intrinsik untuk meyelesaikan suatu pekerjaan.

\section{Motivasi Intrinsik dan Kineria}

Hubungan motivasi intrinsik terhadap kinerja sagat positif, hal itu disampaikan oleh beberapa peneliti antara lain: Deci (1971) mengatakan: umpan balik kinerja positif meningkatkan motivasi intrinsik. Umpan balik bisa berupa ungkapan yang berisi informasi tentang kinerja, jika informasi tersebut berisi informasi kinerja positif seseorang, maka akan meningkatkan motivasi intrinsik orang tersebut untuk meningkatkan kualitas kinerja.

Motivasi intrinsik terlihat jika seseorang sudah merasa tertarik pada sebuah tugas dan berusaha terlibat lebih dalam dalam tugas, seperti yang disampaikan oleh Edward \& Ryan (1985) yang mengatakan: Motivasi intrinsik mengacu pada proses di mana individu tertarik pada tugas itu sendiri, dan diarahkan sendiri untuk terlibat dalam pekerjaan. Seseorang dikatakan termotivasi secara intrinsik untuk melakukan sebuah tugas jika orang tersebut memang tertarik untuk melakukan tugas tersebut dan berusaha untuk semakin terlibat dapam menyelesaikan tugas tersebut. Ini juga diamini oleh Dysvik \& Kuvaas (2011) yang mengatakan: Motivasi intrinsik membuat orang cenderung meningkatkan keterlibatan mereka dalam kegiatan terkait kerja. BenNer \& Putterman (1998) mengatakan bahwa motivasi intrinsik dapat menunjukkan 2 hal, yaitu kesenangan/ketertarikan pribadi khususnya ttg pengembangan profesional, serta ketertarikan pada hal lainnya seperti perhatian pada kebutuhan komunitasnya. Motivasi intrinsik akan mendorong seseorang lebih profesional dalam melakukan pekerjaan. 


\section{Motivasi Intrinsik dan Aktualisasi Diri}

Deci (1975) juga mengatakan: Seseorang dikatakan secara intrinsik termotivasi untuk melakukan suatu aktivitas ketika dia tidak menerima hadiah yang jelas kecuali aktivitas itu sendiri. Jika seseorang termotivasi secara intrinsik untuk melakukan suatu aktivitas, makan dia kana menganggap bahwa melakukan aktivitas tersebut sudah menjadi reward karena dia mendapatkan kepuasan dengan melakukan aktivitas tersebut. Hal ini ditegaskan lagi oleh Deci \& Ryan (1985) yang mengatakan bahwa motivasi intrinsik itu jika seseorang melakukan suatu kegiatan untuk kepuasan yang melekat pada kegiatan tersebut.

Hal ini juga dikatakan oleh Amabile et.al, (1994) yang mengatakan bahwa motivasi intrinsik mengacu pada melakukan kegiatan untuk kepentingan dan kesenangan dari pekerjaan itu sendiri. Hal ini sangat jelas bahwa seseorang termotivasi secara intrinsik jika dia melakukan suatu kegiatan untuk kepentingannya dan kepuasan dari pekerjaan itu sendiri. Motivasi intrinsik sering muncul dari reaksi positif individu terhadap tugas itu sendiri, seperti minat, keterlibatan, keingintahuan, kepuasan, atau tantangan positif, yang berfungsi sebagai jenis hadiah pekerjaan. Jika seseorang mendapatkan reaksi yang positif setelah melaksanakan tugas, berarti dia telah termotivasi intrinsik untuk melaksanakan tugas tersebut.

Tidak ada fenomena tunggal yang mencerminkan potensi positif dari sifat manusia sebanyak motivasi intrinsik, kecenderungan yang melekat untuk mencari hal baru dan tantangan, untuk memperluas dan menggunakan kapasitas seseorang, untuk mengeksplorasi, dan untuk belajar. Salah satu bentuk aktualisasi diri yang didapatkan oleh seseorang adalah mencari hal baru dan tantangan, itu semua timbul dalam motivasi intrinsik.

\section{KESIMPULAN}

Berdasarkan hasil kajian teori yang telah dilakukan oleh penulis, dapat disimpulkan bahwa motivasi intrinsik sangatlah penting, selain mempengaruhi kinerja, motivasi intrinsik juga merupakan wujud untuk memenuhi kebutuhkan untuk mengaktualisasikan diri.
Motivasi intrinsik ini penting karena setiap individu mempunyai individual differences yang membedakan dengan orang lain. Individual differences ini meliputi kesenangan, tingkat kepuasan, kemampuan penyesuaian diri, tingkat emosi dan kerentanan. Salah satu pandangan tentang motivasi intrinsik menekankan pada determinasi diri, dimana dalam pandangan ini mereka percaya bahwa mereka melakukan sesuatu karena kemauan diri mereka sendiri bukan karena kesuksesan, pamor atau imbalan eksternal lainnya (Rainey,1965). Sebagai contoh, karyawan yang sampai bekerja lembur karena ia merasa ingin memenuhi tanggung jawabnya dan segera menyelesaikan pekerjaannya, bukan karena kompensasi dana lebih yang akan ia dapatkan ketika ia bekerja lembur. Orang yang termotivasi secara intrinsik cenderung akan bekerja lebih keras dan memiliki disiplin kerja yang tinggi. Ini berarti karyawan tersebut ingin memenuhi kebutuhan untuk mengaktualisasi dirinya dan secara tidak langsung juga meningkatkan kinerja bukan karena motivasi eksternal seperti kompensasi berupa materi.

Aktualisasi diri didapatkan ketika ketika karyawan termotivasi secara intrinsik dan timbul secara alami keinginan untuk belajar lebih dan bekerja lebih keras untuk mengejar pencapaian kinerja mereka semaksimal mungkin, dan tanpa disadari mereka telah mengeksplorasi keingintahuan mereka (Ryan \& Deci, 2000). Dengan demikian dapat disimpulkan bahwa motivasi intrinsik cenderung mendorong karyawan untuk lebih memfokuskan diri dalam pencapaian tujuan kinerja suatu organisasi (Amabile et al, 1994; Ryan \& Deci, 2000).

\section{DAFTAR PUSTAKA}

Amabile, T. M. 1993. Motivational Synergy: Toward New Conceptualizations Of Intrinsic and Extrinsic Motivation in The Workplace. Human Resource Management Review. Vol 3 (3). 185-201 pp.

Amabile, T. M., Conti, R., Coon, H., Lazenby, J., \& Herron, M. 1996. Assessing The Work Environment for Creativity. Academy of Management Journal. Vol 39 (5). 1154-1184 pp. 
Amabile, T. M., Hill, K. G., Hennessey, B. A., \& Tighe, E. 1994. The Work Preference Inventory: Assessing Intrinsic and Extrinsic Motivational Orientations. Journal of Personality and Social Psychology. Vol 66 (5). 950-967 pp.

Ben-Ner, A., \& Putterman, L. 1998. Economics, Values, and Organisations. Cambridge MA: Cambridge University Press.

Deci, E. L. 1971. Effects of Externally Mediated Rewards on Intrinsic Motivation. Journal of Personality and Social Psychology. Vol 18. 105-115 pp.
Deci, E. L. (1975). Intrinsic motivation. New York: Plenum Press.

Deci, E. L., \& Ryan, R. M. 2000. SelfDetermination Theory and The Facilitation of Intrinsic Motivation, Social Development and Well-Being. American Psychologist. Vol 55. 68-78 pp.

Edward, D., \& Ryan, R. 1985. Intrinsic Motivation and Self-determination in Human Behavior. New York: Pantheon.

Pittman, T. S. and J. F. Heller: 1987. Social Motivation. Annual Review of Psychology 38. 461-489 pp. 